\title{
War and Peace in The Law of Peoples: Rawls, Kant and the Use of Force ${ }^{1}$
}

\author{
PERI ROBERTS
}

Cardiff University

Email: robertspm@cardiff.ac.uk

\begin{abstract}
Where Rawls's The Law of Peoples addresses war and the use of force then his position has often been identified closely with Walzer's restatement of Just War Theory, as both positions appear to take nation states, and the conflicts between them, to be the bedrock of the international system. On the other hand, Kant's notion of a peaceful federation of states presents us with the notion of a world without war and where the international system is transformed. This article argues that Rawls's account of the use of force is better understood if we read it with an eye to its resonances with Kant rather than with Walzer. Doing so rewards us with a clearer understanding of central aspects of Rawls's account of Just War and vision of international politics.
\end{abstract}

\section{Keywords:}

John Rawls, Just War Theory, Peace, Intervention

\section{Introduction}

Consideration of contemporary just war theory often takes Michael Walzer to be its touchstone. This has been the case since the publication of Just and Unjust Wars in 1977 (Walzer 2006). Such is his centrality to contemporary accounts of just war theory that when Rawls discusses the international use of force in The Law of Peoples he says, 'I follow here Michael Walzer's Just and Unjust Wars... This is an impressive work, and what I say does not, I think, depart from it in any significant respect' (Rawls 1999: 95n.8). Commentators often agree with Rawls's self-assessment with Maffettone, for example, suggesting that 'Rawls' discussion of war is not particularly original and it relies substantially on Michael Walzer's theory' (Maffettone 2010: 
307). ${ }^{2}$ Howard Williams contrasts what he calls the Hegelian character of Walzer-style just war theory with a Kantian alternative and goes on to conclude that 'Rawls treads a fine line between Kantianism and Hegelianism. Arguably with just war theory he steps over more into the Hegelian than the Kantian realm' (2012: 165).

Williams characterizes just war theory like Walzer's as Hegelian because it takes the nation state as the bedrock of the international system and shares Hegel's scepticism about the possibility and functioning of a peaceful federation of free states (2012: 169). In doing so it accepts that war is a normal and ongoing part of international relations as an unavoidable instrument of foreign policy (Williams, Howard 2012: 143 \& 165). Finally, it regards individual states themselves as solely positioned to judge just cause: when war is necessary in defence against aggression, in anticipation of aggression yet to happen and, in some cases of aggressive intervention in another state. In some contemporary just war theory this has evolved into a power (or group of powers) making and imposing their judgements about rightful force on all other states (e.g. in the name of a 'duty to protect') (Williams, Howard 2012: 145 \& $165)$.

Kant's account of war and the use of force is drawn very differently from this when he states that 'morally practical reason pronounces in us its irresistible veto: there is to be no war' (MM, 6:354). ${ }^{3}$ Williams draws this out into several features of Kant's approach. Firstly, it depicts war as 'part of the pathology of human history' and 'not a normal human activity'; even if the occurrence of war is an unavoidable anthropological starting point for international law and politics it should not be accepted as unchangeable fact (Williams, Howard 2012: 167, 152 \& 107). Secondly, Kant therefore dismisses just war theory (and so can be interpreted as having no just war theory of his own) instead arguing that, thirdly, the highest political good is perpetual peace (Williams, Howard 2012: 167) ${ }^{4}$ and even jus in bello restrictions on fighting 
wars can only make any sense in connection with the project of establishing this condition of perpetual peace (Williams, Howard 2012: 152). Fourthly, Kant argues that a prime feature of his preferred republican mode of government is that it promotes peace as a consequence of its reluctance to sanction the use of force because of the involvement (through their representatives) of their citizens in political decision-making (Williams, Howard 2012: 108). Finally, Kant advances wholesale reform of international politics as a federation of free republican states, transforming international law into a system of rights that upholds peace rather than maintains the possibility of war (Williams, Howard 2012: 168).

It is not difficult to see why Rawls is often thought to be lining up with Walzer rather than Kant on questions of the international use of force. Rawls, as we have seen, self-identifies with Walzer when discussing these issues. He also, as we shall see, clearly has a just war theory of his own that makes it clear that force has some role to play in international politics. Finally, he has been generally regarded by cosmopolitan critics to be placing too much emphasis on the state as the basis of the international system. ${ }^{5}$ However, this paper will respond to these understandings of Rawls's account of the international use of force, arguing that we better understand Rawls's account if we read it with a Kantian position in mind rather than a Walzerian one. To be clear, this paper does not intend to advance any claim of its own about whether Kant has a just war theory of his own nor, indeed, is it intended to advance any claims to a novel Kantian interpretation of any sort. Instead, the paper is focused on reading Rawls, working with the features of Kant's position just identified, and demonstrating that there is much in Rawls's position that resonates particularly strongly with these features. The first section will briefly sketch an account of Rawls's vision in The Law of Peoples that draws attention to these resonances with Kant's understanding of international peace. The next section takes this sketch and shows how it is useful in helping to better understand the central positions that Rawls expressly adopts when discussing the international use of force. The third section 
pulls out, for further consideration, two more puzzling aspects of Rawls's position and argues that this sketch may help us cast light on the potential resolutions to those puzzles. Finally, the paper will conclude that, when considering war and peace, Rawls does indeed have much in common with Kant.

\section{Rawls's 'realistic utopian' vision}

The first step in making good on these thoughts is to try to establish that Rawls's account of the use of force is better understood in terms of its long-term focus on peace and that, although force may play a role in bringing about future peace, those future peaceful relations would not continue to be defined by warlike interactions. Rawls acknowledges that he is 'greatly indebted to Kant's idea of the foedus pacificum' or a league of peace (1999: 86). In an unpublished paper, Huw Williams has convincingly argued that,

Rawls' approach is characterised by the Kantian idea that peace is the regulative principle of war... [and that] Rawls' just war doctrine represents principles of transitional justice, moving from the non-ideal state of war to the ideal state of perpetual peace.

Huw Williams argues that Rawls agrees with Kant's judgement that 'war is a highly regrettable part of the practice of international politics as it is', that they share 'the key idea that we can and should move towards a stable peace' and that 'the transitional principles of just war can be dispensed with in a future realistic utopia' (Williams, Huw: 7, 13 \& 14).

If we stand back and look at the big picture, Rawls appears to agree with Kant that war is a pathological feature of international politics as we have experienced it and that the long term aim is to eradicate it. Whatever differing judgements we might have about the usefulness of 
Rawls's distinction between ideal and non-ideal theory it is clear that Rawls intends his account of realistic utopia to be part of what he calls ideal theory and that it is characterized by a Society of Peoples who together follow the principles of a peaceful Law of Peoples to govern their interactions. What makes the world we actually live in non-ideal is the existence of what Rawls calls the 'great evils of human history'; unjust war and oppression, religious persecution and the denial of liberty of conscience, starvation and poverty, genocide and mass murder, and slavery (Rawls 1999: 6-7 \& 126). Rawls argues that these evils follow from political injustice and that once these 'gravest forms of political injustice are eliminated by... establishing just (or at least decent) basic institutions, these great evils will eventually disappear' (1999: 7 \& 126). He says,

I call a world in which these great evils have been eliminated and just (or at least decent) basic institutions established by both liberal and decent peoples who honor the Law of Peoples a "realistic utopia"... [This] shows us, in the tradition of... Kant, the social conditions under which we can reasonably hope that all liberal and decent peoples may belong, as members of good standing, to a reasonable Society of Peoples' (Rawls 1999: 126).

The argument is that over time liberal and decent but non-liberal societies will come to accept (for good reasons) a Law of Peoples to govern their interactions and to enable the peaceful resolution of any disputes that arise between them. To this end we can expect that these peoples would establish cooperative associations and federations similar to the United Nations ideally conceived (Rawls 1999: 36) which Rawls refers to as ‘a Confederation of Peoples' (along with a fair trade organization and a cooperative international banking system) (1999: 42). Indeed, evidence that Rawls regards such a confederation as central to his conception of a Society of Peoples is that he is very clear that the guidelines for its formation are part of what is agreed in 
the original position, at the same time as there is agreement on the eight principles of the Law of Peoples (1999: 42-3). Behind the veil of ignorance liberal and non-liberal but decent peoples will agree that such a confederation is necessary. So, Rawls is outlining an ideal for international politics of a Society of Peoples in a lawful condition governing themselves under a Law of Peoples and as part of a peaceful Confederation of Peoples (1999: 93). In this ordered international politics there is no space for war as a decision procedure, nor for war as punishment, extermination of enemies or as a teaching tool (TTP, 8:346-7 \& 8:356-7). Rawls also claims that such an ideal is at least possible given an assessment of the best available evidence when he places such store by the Democratic Peace Thesis that properly organized democratic states do actually find cooperative alternatives to war when they fall into dispute (1999: 44). ${ }^{6}$

It is clear that we do not yet live in a world where this ideal is realized. Great evils persist, most especially in relation to non-well-ordered societies - outlaw states, burdened societies and benevolent absolutisms - and Rawls's non-ideal theory is concerned with guiding liberal and decent regimes in their interactions with these societies. Non-ideal theory directly addresses the great evils of unjust war, oppression, starvation and poverty, genocide and mass murder where liberal and decent societies are under an injunction to act in ways that further the ideals of the Law of Peoples. That is, they should:

1. Assist societies whose institutions do not enable them to efficiently combat starvation and extreme poverty (Rawls 1999: 106)

2. Respond with force in self-defense (or the defense of others) when subject to aggressive attack (unjust war) (Rawls 1999: 91)

3. Potentially forcefully intervene in outlaw states to prevent mass murder and genocide (Rawls 1999: 93-4n.6). 
2. and 3. fall under Rawls's approach to the just use of force and constitute part (along with in bello conditions on the waging of war) of his account of Just War. These responses to injustice in the non-ideal world are targeted at the elimination of these political injustices and so towards the eradication of the evils that they cause. In engaging with the non-ideal the actions of wellordered societies should be guided by the possibility of a Society of Peoples in ordered and lawful relations. As Huw Williams argues, Rawls finds war justifiable only in this transition from the non-ideal to the ideal Williams, Huw: 1). The overarching hope of Rawls's non-ideal theory is to bring about a world in which there are no outlaw states nor any societies burdened. As Kant argues that a condition of perpetual peace is that 'the civil constitution of every nation should be republican' (TTP, 8:349) so Rawls says that, 'the aim of the Law of Peoples would be fully achieved when all societies have been able to establish either a liberal or a decent regime, however unlikely that may be' (1999: 5). Rawls, like Kant, explicitly links the issue of internal political order to the issue of external political relations - peoples rightly organized domestically are the condition of a peaceful and ordered world (more on this later).

Of course, in the fraught world of international politics and foreign policy it will not always be clear, in any particular case, what action will be the best course to adopt to further approach this ideal. It is not simply a matter of reading off prescriptions for action from the ideal picture and applying them to the non-ideal world. We might expect trial and error in actual decisionmaking to result in a lot of error and many trials. We would also expect that people motivated by envy, pride, desire, power and status will often act instrumentally in their pursuit (even if they usually cloak this in very different language). However, both Rawls and Kant think we should, at all times, bear in mind the future possibility of perpetual peace or of a peaceful Society of Peoples under a Law of Peoples that shapes their interactions: effectively a vision of a law-governed international order, as a regulative ideal in our political decision-making and foreign policy actions (Rawls 1999: 22-3. MM, 6:354-5). This is so even if we are not very 
confident at all about either bringing it about, or about what would, in any particular situation, constitute a progressive step towards it. If we do not hold this possibility in mind, if we are amoral, incurably cynical and self-centred, Rawls ends The Law of Peoples saying 'one might ask, with Kant, whether it is worthwhile for human beings to live on the earth' (Rawls 1999: 128).

So, on an initial examination we might provisionally conclude that Rawls's law of peoples can plausibly be understood in terms of its resonances with the five features of Kant's account laid out in the introduction. Firstly, like Kant, Rawls is treating war as a pathological condition to be eliminated not as an unchanging fact of international politics. So, secondly, although he does have a theory of just war it is clearly limited and the use of force can be justifiable only in service of the transition towards the ideal. Thirdly, this ideal, broadly shared by Rawls and Kant, is of a world characterized by a truly peaceful Society of Peoples. Fourthly, also like Kant, achieving such a peaceful world is dependent on the existence of peoples whose internal politics is appropriately organized. Finally, the reform of international politics involved in bringing about the transition to a peaceful world requires the creation of a Confederation of Peoples under a Law of Peoples that governs their interactions in an ordered and lawful manner.

\section{Rawls and the International Use of Force}

The next step in this paper is to take this outline understanding of Rawls's approach and consider if it is useful in helping us to understand the positions that Rawls expressly adopts when discussing the use of and limits on force in The Law of Peoples, and also very briefly to ask if it enables us to consider plausible extensions to those aspects of the use of and limits on force that are not expressly addressed by Rawls. Sometimes this is straightforward and quick, other times this involves a little more work. It is argued that, at almost every point, we can 
understand the positions that Rawls does, or could, adopt as reflecting the injunction to always keep an eye on this regulative ideal of the future possibility of peace and the idea of a lawful regulated international order as achievable in principle. We can also note the clear contrasts with a position like Walzer's.

\section{Understanding the well-ordered peoples' right to self-defense}

In The Law of Peoples Rawls is explicit that well-ordered peoples, both liberal and decent but non-liberal, living as we are in a non-ideal world have a right to defend themselves against aggressive attack. Liberal peoples have this right on the basis of a need to protect and preserve the basic rights and freedoms of their citizens and to protect their democratic political institutions (Rawls 1999: 91). Decent but non-liberal peoples also have this right to self-defense on the basis that they 'also have something worth defending', a society that respects and honours the human rights of its members coupled with decent political arrangements motivated by a common good sense of justice (Rawls 1999: 92). The right to self-defense in both cases recognizes that unjust aggressive attack for gain, punishment or glory is an attack on the idea of a peaceful world regulated in an ordered and lawful manner. It is also an attack on the examples of well-ordered lawful regimes already existing in the world. For these reasons such attack can rightly be resisted.

\section{Understanding the lack of right to self-defense for some states}

Rawls denies outlaw states (those states that are either aggressive externally, severely repressive internally, or both) a right to self-defense, and by implication it is also denied to burdened societies (those states that are institutionally unable to deliver adequately on human rights for their members) (Rawls 1999: 91-2). Rawls mostly discusses outlaws and two situations in which, if subject to force, they may not rightly respond with force of their own. Firstly, they might be subject to a war of self-defense by one or more well-ordered societies 
responding to that outlaw state's own aggressive attack on them. Secondly, there are circumstances in which they might be subject to intervention by well-ordered societies on the basis of their egregious and severe violations of human rights that persist in the face of actions short of forceful intervention, such as sanctions(Rawls 1999:93-4n.6). In neither case does Rawls regard the outlaw state as having a right to defend itself (although, of course, it probably will defend itself in reality). The outlaw regime has either attacked well-ordered members of a Society of Peoples so illegitimately putting citizens of their own society and others in a situation of war, or as aggressors against their own people they are illegitimately and systematically violating their rights. The first is a direct attack not only on a well-ordered state(s) but also on the idea of a lawfully regulated Society of Peoples and so on the possibility of peace. The second is an attack on the human rights at the basis of that peaceful ideal, as well as possibly killing a lot of people.

\section{Understanding other instances of the defensive use of force}

This last point also explains why Rawls does regard benevolent absolutist societies as having a right to self-defense as they too have something worth defending (1999: 92). They may not be well-ordered with decent political institutions but they do, in practice, both respect the human rights of their own subjects and act peacefully towards their neighbours. So, despite not being well-ordered, and so they could not be members of the Society of Peoples under a Law of Peoples, they do not threaten either whatever progress we have made towards a such a peaceful Society nor the possibility of such a Society developing in the future.

By extension this might also help us to think about uses of force that Rawls does not explicitly cover, such as when one outlaw state attacks another. Now although neither state is part of the Society of Peoples well-ordered peoples will still need to consider how to respond to violence that occurs, and not just because of the danger of instability spreading to well-ordered 
territories. The foreign policy of well-ordered peoples could, guided by the hope and possibility of a lawful international order in which human rights are respected everywhere and the evils of unjust war and mass murder overcome, regard an outlaw state attacked by another outlaw as rightfully defending its citizens against aggressive war, even if it was ordinarily no defender of their rights. Well-ordered peoples might take this position because aggressive war is never aimed at peaceful order and, unlike in the case of humanitarian intervention, the target of force is not restricted to the regime's leaders (and military if necessary) and in bello restrictions on targeting civilians are less likely to be observed by an outlaw invader. The same conclusion might be drawn if a burdened society comes under attack from an outlaw.

\section{Understanding that the right to self-defense has its basis in the Law of Peoples}

To well-ordered societies considering their foreign policy with an eye on the ideal of a lawfully regulated international order it should really matter whether a state had a right to self-defense or was simply defending itself. The second is a description of their action whilst the first is a recognition of the lawful nature of that action. The necessity of using force in accordance with a right is entirely regrettable but probably not blameworthy. Well-ordered societies, as part of a Society of Peoples characterized as a Confederation, can appeal to the Confederation to legitimize their action and verify its legality under the lawful regulation of the Law of Peoples. The use of force not in accordance with a right is, on the other hand, an attack on the ideal of the lawful regulation of international politics and so might open the leaders of such regimes to prosecution as criminals at the end of the conflict.

This also reflects the much broader point, that Rawls's account of self-defense and its basis is distinctly different from that in Walzer's contemporary version of just war theory. For Walzer, 'self-defense seems the primary and indisputable right of any political community, merely because it is there' (2006: 82. Emphasis in the original). For Walzer, 'any use of force... by 
one state against the political sovereignty or territorial integrity of another constitutes aggression' and 'aggression justifies... violent response' (2006: 62). This conception is clearly state-based. For Rawls, on the other hand, the right to use force in defense is not based in any state's mere existence. Rather, 'the basis of that right depends on the Law of Peoples' and 'the war powers of governments, whatever they might be, are only those acceptable within a reasonable Law of Peoples' (Rawls 1999: 26). Again, even in the non-ideal world we inhabit, force is only justifiable if captured under ordered regulation, sanctioned by the Law of Peoples and thus is consistent with holding the ideal of a lawfully regulated international politics at the front of our minds.

\section{Understanding In bello rules in the Law of Peoples}

Finally in this section, the law of peoples' restrictions on conduct in war are explicitly designed with the idea of a future peace in mind (Rawls 1999: 94) and so contain traditional restrictions on waging war concerning respecting the rights of enemy combatants, limits on the place of cost-benefit analysis and on the deliberate targeting of civilians, for example (Rawls 1999: 947). Let us pick out the one issue of deliberately targeting civilians for closer attention. This injunction, both in Walzer and in Rawls, is not absolute. Both hold that under conditions of 'supreme emergency' the constraint might be relaxed, a supreme emergency exemption be in place, and civilian populations deliberately targeted. Both argue that Britain faced a supreme emergency when under attack between 1939 until at least late 1941, thus legitimating the bombing of German cities in 1940. Both are also clear that no such emergency was in place by the 1945 fire-bombing of cities such as Dresden nor was it when the USA dropped atomic bombs on Japan.

Walzer argues that a supreme emergency exemption must satisfy two criteria. One, the immanence of danger; the threat to the community must be close and pressing. Two, the nature 
of the danger 'must be of an unusual and horrible kind', threatening the existence of the political community itself (Walzer 2006: 252-3). Both these criteria must be met, placing political leaders in a position where 'they will do what they must to save their own people' and they may 'override the rights of innocent people for the sake of their own political community' (Walzer 2006: 254). Recognising that the exemption legitimates 'great immoralities' he argues that it does so 'only in the face of a far greater immorality...attack on the very existence of a particular community' (Walzer 2004: 50). So, when Walzer poses himself the question 'Can a supreme emergency be constituted by a particular threat... against a single nation?' he responds 'I am inclined to answer this question affirmatively' (Walzer 2006: 254).

Rawls is less clear than Walzer about exactly what the criteria for an exemption are, but is clear enough.

$$
\begin{aligned}
& \text { Whether the supreme emergency exemption applies depends on certain } \\
& \text { circumstances...Britain's bombing of Germany until the end of } 1941 \text { or } 1942 \text { could be } \\
& \text { justified because Germany could not be allowed to win the war, and this for two basic } \\
& \text { reasons. First, Nazism portended incalculable moral and political evil for civilized life } \\
& \text { everywhere. Second, the nature and history of constitutional democracy and its place } \\
& \text { in European history were at stake (Rawls 1999: } 99 \text {. Emphasis added). }
\end{aligned}
$$

Key here is that neither criteria, however imprecisely stated, refers to the threat to any particular political community. Rawls goes on immediately to write,

Churchill really did not exaggerate when he said... "if we fail...the whole world including the United States will sink into a new Dark Age". This kind of threat, in sum, justifies invoking the supreme emergency exemption, on behalf not only of constitutional democracies, but of all well-ordered societies (1999: 99. Emphasis added). 
This is the only passage in The Law of Peoples where Rawls discusses the application of the supreme emergency exemption and nowhere is the threat to a particular community mentioned. The threat that Rawls discusses is much broader in scope. It is a threat to 'civilized life', to 'the nature and history of constitutional democracy' and is to be invoked on behalf of all wellordered societies. The exemption is invoked in defense against a threat to well-orderedness in the world rather than in defense of any particular polity, well-ordered or not. Even in discussion of Britain in 1940, where Walzer makes it clear that the ground for invoking the exemption is a supreme emergency constituted by a threat to Britain's survival as a distinct political community, Rawls never makes Britain's survival an issue in itself. It is not at all clear that Rawls's exemption could be invoked by a single polity even under threat of extinction, if it was not facing at the same time a general threat to the existence of civilized life or wellorderedness in the world.

It has been worthwhile spending a little time on this in order to draw out just how far from advancing a state-centred theory Rawls can be, even in the face of direst threat. Taking his text at face value, relaxing the prohibition on the otherwise unlawful deliberate targeting of civilians is not a justifiable response even by a state facing an existential threat. This would undermine in bello restrictions imposed by the Law of Peoples. It is only when the possibility of a future peaceful and regulated international order is itself at risk due to the threat to well-orderedness in the world that such extreme measures can even be considered. To reiterate, Rawls's understanding of a right to self-defense (and its limits) is based not on the fact of a state's existence (as Walzer's Hegelianism would have it) but on its basis in the Kantian notion of the Law of Peoples governing a Confederation of Peoples. ${ }^{7}$

In summary, this section aimed to show that the sketch of Rawls's project in The Law of Peoples resonates with central features of Kant's position laid out above, whilst illustrating and 
explaining some of the central and defining positions on the use of force that Rawls adopts. From the right to self-defense of well-ordered societies and benevolent absolutisms, to the lack of self-defensive rights for outlaw states (in most instances), to the basis of these defensive rights in law rather than a state's existence, through to the strictness of limits on the emergency use of force, we gain a clearer understanding if we interpret them through the recognition that the possibility of a peaceful and law-governed international order is working as the core regulative ideal throughout The Law of Peoples.

\section{Rawls's potential Kantian responses to further questions about the law of peoples}

The final substantive section of this paper takes a little time to address two more puzzling issues with Rawls's law of peoples and tries to show that, once again, if we pay closer attention to the resonances with Kant at key junctures then we may further our understanding of the way The Law of Peoples works. Of course, this will barely scratch the surface of possible issues for consideration. However, these two issues are selected simply to illustrate a general point about the interpretive usefulness of reading The Law of Peoples, bearing its resonances with central features of Kant's position in mind.

i. Limits on forceful intervention - why not intervene in all societies that are not wellordered?

Benevolent absolutist societies occupy a strange position in The Law of Peoples. They have a right to defend themselves despite being not well-ordered, though they are non-aggressive. Although they happen not to infringe the basic human rights of their subjects they lack the desire or the political institutions to give those subjects a meaningful role in political decision making (Rawls 1999: 4). Ideal theory has no place for benevolent absolutist societies yet Rawls does not make them subjects of potential military intervention as in the case of some outlaw 
states (or even of assistance-focused intervention as in the case of burdened societies). We have already seen that benevolent absolutist societies are not directly threatening of whatever peace we currently have or of the possibility held out by the regulative ideal, but still it is worth thinking further on why intervention to bring about regime change (perhaps through forced democratisation) does not seem justifiable to Rawls in this case. In fact, Rawls's limits on intervention are much more extensive than this as he does not sanction such interventions in the case of most non-aggressive outlaw states either, if their human rights violations are not systematic and egregious (1999: 93-4n.6). This is puzzling. If the realistic utopia of a Society of Peoples under a Law of Peoples depends, as Rawls thinks it does, on all peoples being wellordered then why does his non-ideal theory not sanction intervention in all societies that are not yet well-ordered? If there is no place in ideal theory for these societies then why should well-ordered peoples not do what they can to make them well-ordered?

If we turn to Kant for comparison this may be helpful. Kant argues that 'the transition from an international state of nature to a settled civil condition cannot and should not occur by force' (Williams, Howard 2012: 57). He is clear that the congress of states is to be 'a voluntary coalition' rather than an association where a state is subjected 'to someone else's concept of right' MM, 6350-1 and TPP, 8:356). Instead of being propagated by force Kant argues that an existing example of lawful and peaceful relations can act as a pull on others, 'a focal point for a federal association among other nations that will join it' freely (TTP, 8:356). In this manner Kant has faith in 'an enduring, ever expanding federation that prevents war'(TTP, 8:357) by respecting the equal status of members (TTP, 8:356) who freely agree to resolve their disputes by 'in a civil way, as if by a lawsuit, rather than...by war' (MM, 6:351).

With this in mind we can think about the strict limitation of Rawls's forceful interventions to only some, and not even all, outlaw states and certainly not to benevolent absolutisms. Again, 
why not intervene in any society that is not well-ordered in order to make them so? Firstly, we need to get clear that even when Rawls does permit military intervention, force is not being used for this end (forcing the transition to well-orderedness). Instead military intervention is only permitted when absolutely necessary to stop systematic, egregious and persistent violations of human rights. The only example of justified forceful intervention that Rawls provides is in a regime that keeps its lower classes as slaves and uses them in a system of human sacrifice. In this case 'intervention in the defense of human rights would be acceptable and would be called for' (1999: 93-4n.6). Note, in all other cases unlike this quite extreme example, that is benevolent absolutisms, burdened societies, 'moderate' outlaws and 'extreme' outlaws who respond to means short of force, Rawls argues that peaceful and non-military influence is the appropriate response. The foreign policy of well-ordered societies should be built on peaceful persuasion, offering incentives to cooperate, offering assistance to burdened societies and, in difficult cases, the imposition of sanctions regimes.

So, force is not sanctioned in order to bring about commitment to the Law of Peoples but only to stop terrible human rights violations (or in self-defense). Of course, once we find ourselves in the position of having forcefully intervened as a last resort into an unpersuaded 'extreme' outlaw in defense of human rights then we may very well be under a duty to aid in the establishment, as far as possible, of some form of decent well-ordered regime. Having intervened we will be faced with legitimate post bellum obligations. This much might follow from a recognition that 'the present enemy must be seen as a future associate in a shared and just peace' (Rawls 1999: 101). Regime change, however, cannot be the justifying reason for intervention.

For Rawls, like Kant, commitment to the Law of Peoples should be freely chosen between equals. This is modelled in the original position, for example (1999: 33 \& 35), and recognized 
in the list of principles of the Law of Peoples (1999: 37). Only in this way will the Society of Peoples exhibit the values of reciprocity and mutual respect that are at the heart of Rawls's ideal (1999: $41 \& 121$ and $62 \&$ 122). Force and fear are not appropriate motivations for membership of a Society of Peoples. So, despite his recognition that well-ordered peoples 'simply do not tolerate outlaw states' and 'have a prima facie case for intervention...in such cases', Rawls does not regard military interventions as the appropriate expression of this intolerance (1999: 81 \& 93n.6). Instead he claims, like Kant, that the examples of well-ordered institutions exercise a pull that is likely to be more persuasive than coerced regime change could ever be (1999: 62). So, and for related reasons, Rawls rejects forced democratisation in an echo of Kant's rejection of forced republicanism (TTP, 8:356), despite their shared recognition that an increase in the scope of democracy or republicanism would further their ideal of a peaceful world.

ii. Why extend the democratic peace thesis to decent societies?

A central feature of the law of peoples is Rawls's acceptance of the democratic peace thesis coupled with an effective claim about its equal applicability to decent but non-liberal and nondemocratic societies. However, Moellendorf, for example, argues that 'the basis for Rawls's extension... to cover decent hierarchical societies is lacking. Rather than developing that basis in any detail he merely stipulates that such people are peaceful' (2014: 391). He argues that this is because the express basis that Rawls gives for democratic peace, a version of 'peace by satisfaction' where 'liberal peoples have nothing to go to war about' as they live in a reasonably just well-ordered society (Rawls 1999: 47) does not apply to decent non-liberal societies. A reasonably just well-ordered society, Rawls argues, meets five conditions:
a) Fair equality of opportunity
b) A decent distribution of income and wealth 

c) Society as employer of last resort
d) Basic health care assured for all
e) Public financing of elections (1999: 50).

'To the extent that constitutional democratic peoples have features a) through e), their conduct supports the idea of a democratic peace' (Rawls 1999: 51). Moellendorf concludes that since decent but non-liberal societies do not have features a) through e) there is no support for Rawls's apparent extension to cover them. ${ }^{8}$ Undeniably, however, Rawls does think this extension is merited. Recall that he says that the peaceful aim of the Law of Peoples 'would be fully achieved when all societies have been able to establish either a liberal or a decent regime' (1999: 5. Emphasis added). Note that he is explicit here. A world where liberal and decent but non-liberal societies live alongside each other in cooperative relations marks the full achievement of his aims in ideal theory and need not be regarded as merely acceptable, or as a transitional state on the road to a fully liberal world. It is particularly puzzling, then, that having laid out the conditions of democratic peace so explicitly Rawls does not seem to offer a clear explanation for its extension to at least some non-democratic peoples who do not satisfy these conditions.

Again, returning to Kant's Perpetual Peace may help us come to a clearer conclusion about what, other than stipulation, Rawls might take to underpin the extension of the peace thesis to decent but non-liberal societies. Here I have in mind the features of the republican mode of government that is at the heart of Perpetual Peace. One of Kant's main reasons for thinking of republics as peaceful is that, in some form, 'the consent of the citizenry is required in order to determine whether or not there will be war' (TTP, 8:351). Citizens, through their representatives, will vote against calls for war on spurious or instrumental grounds as they will bear the mortal and financial costs of waging war. Forms of government that are not republican 
are despotic and under such a 'nonrepublican constitution... the easiest thing in the world is to declare war'(TTP, 8:351-2). A key to perpetual peace for Kant is, then, the involvement, through their representatives, of citizens in political decision making.

Let's return to Rawls's extension of the peace thesis from liberal democracies (who we will assume meet this Kantian condition that citizens be politically involved) to decent non-liberal, non-democratic societies but not, for example, to benevolent absolutisms. It is significant that Rawls extends the peace thesis to what he calls decent societies and no further. In his account of how a decent society may be politically organized Rawls lays out the idea of a decent consultation hierarchy (1999: 71). Such societies might regard members as each belonging 'to a group represented by a body in the consultation hierarchy' (1999: 71-2).

'In political decisions a decent consultation hierarchy allows an opportunity for different voices to be heard'. 'Persons 'have the right at some point in the procedure of consultation... to express political dissent, and the government has an obligation to take a group's dissent seriously... It is necessary and important that different voices be heard' (1999: 72).

What is distinctive about both democratic and hierarchical consultative societies is that in both cases a key feature of the regime is that they build in mechanisms to feed citizens views (through representatives) into political decision-making including, we assume, about war. This feature is lacking in benevolent absolutisms, and also in burdened societies and outlaws. It is also precisely this feature that distinguishes decent societies from benevolent absolutisms and could explain why Rawls thinks the peace thesis can reasonably be extended to one and not the other. Once again, by paying closer attention to Kant's claims in 'Perpetual Peace' we potentially gain illumination on Rawls's positions in The Law of Peoples. Of course, there are many objections to Rawls's proposed extension of the idea of democratic peace to non-liberal 
peoples. ${ }^{9}$ Addressing the range of these objections has not been the role of this section. Rather, it has only aimed to show that, if we bear in mind Rawls's broadly Kantian approach in The Law of Peoples, then it becomes clear that this extension is not merely stipulative, as Moellendorf suggests, but is based on Rawls's acceptance of Kant's claim that the character of domestic political arrangements is key to long-term peaceful relations between states. $\mathrm{He}$ is convinced that the members of all decent societies, like the members of Kant's republican states, will make their aversion to war very clear to their governments.

\section{Conclusion}

This paper has attempted to offer the beginnings of a reading that takes seriously Rawls's continued return, throughout The Law of Peoples, to Kant and to the idea of a league of peace (foedus pacificum). Returning to our starting point, let us summarize again the clear resonances between Rawls account of the use of force and the characterization of Kant's position that was laid out in the introduction.

Firstly, just as Kant regarded war as pathological so did Rawls. Secondly, although Rawls does have an explicit theory of just war where Kant may not have, as with Kant, Rawls's ad bellum and in bello restrictions on force in non-ideal situations are better understood when connected with the ideal of establishing a peaceful and regulated international order. Thirdly, despite war's pathological nature both argue that the existence of war should not be accepted as unchangeable fact and both envisage the possibility of an ideal peaceful world where there is no war. Fourthly, both Rawls and Kant explicitly link the internal political organization of states to the possibility of peaceful external relations. Finally, both also advocate the reform of international politics through the creation of a federation of peaceful and well-ordered states which transforms international politics into a system of regulated order under law. In Rawls's 
case the centrality of this is emphasized in the way that the guidelines for such a federation are agreed in the original position alongside the basic principles of the law of peoples.

Secondly, laying out these resonances between Rawls and Kant has enabled us to be much clearer about the basis of relatively straightforward central aspects of Rawls's account of force, as briefly explored in the second substantive section above, and about two more puzzling aspects of this account, explored somewhat more fully in the third section.

Finally, let us be clear. This paper is certainly not claiming that Rawls shares wider aspects of Kant's philosophy more generally, nor is it claiming to have explored all The Law of Peoples' links to Kant and 'Perpetual Peace'. However, it does contend that he is Kantian enough when considering the international use of force to distinguish him clearly from any contemporary just war theorists such as Walzer that might be characterized as Hegelian. This is clear as he refuses to accept that war is a normal, ongoing and permanent feature of international politics. Nor does he, when considering use of force, put the state at the heart of international politics. The most striking example of this we have seen is in the limits imposed on the supreme emergency exemption by Rawls that are not imposed by Walzer. Recall that, unlike Walzer who argues that a threat to the ongoing existence of any single state constitutes a supreme emergency, Rawls implies that unless the threat is to the broader existence of well-orderedness in the world then a single state might have to accept its own destruction rather than deliberately target their enemy's civilian populations. Nor is any state positioned to be its own sole legitimate judge of when the use of force is justifiable. Rawls envisages an international organization such as the United Nations (ideally conceived) that would express for the Society of Peoples their condemnation of unjust institutions and clear cases of human rights violation whilst in grave cases it would impose sanctions or organize intervention (1999: 36). In a Society of Peoples under a Law of Peoples, even under non-ideal conditions, war is no longer 
the province of individual states. Finally, therefore, Rawls is not at all sceptical about Kant's vision of the possibility of a peaceful federation of free states. This very possibility is, in contrast, at the core of his Law of Peoples.

\section{Notes}

${ }^{1}$ This paper was originally presented at the Kant and Rawls conference in Cardiff 13-14 October 2017, and my thanks are extended to the participants for their helpful and supportive comments. Further thanks are owed to Huw Williams and an anonymous reviewer for comments on a later draft.

${ }^{2}$ Other commentators who suggest this similarity in Rawls's and Walzer's accounts of the international use of force, in whole or in part, are Chris Brown (2000: 129), who says that Rawls's discussion is 'largely along the lines of Michael Walzer's reasoning’, Christopher Toner (2005: 545-6), stating ‘it is Michael Walzer, whom Rawls follows here' and Brian Orend (2006: 140), who accuses Rawls of 'aping' Walzer.

${ }^{3}$ References to Kant's writings give the volume and page of Kant's Gesammelte Schriften edited by the Royal Prussian Academy. These are included in the margins of the English translations used, and details of these translations are in the list of references. The following abbreviations are used: $\mathrm{MM}=$ The Metaphysics of Morals (Kant 1996); TPP = ‘To Perpetual Peace: A Philosophical Sketch’ (Kant 1983: 107-143).

${ }^{4}$ Thomas Mertens seems to agree that Kant can have no place for a theory of just war (2002: 61-2). On the other hand, Brian Orend (2004) argues that Kant does have a just war theory and Thomas Hill (2012) argues that at least some aspects of one could be developed on Kantian grounds. This paper's argument does not rely on settling this dispute.

${ }^{5}$ For a broad and very helpful examination of the range of debates concerning The Law of Peoples see Martin \& Reidy (2006).

${ }^{6}$ Of course, not all decent peoples are liberal democracies in Rawls's realistic utopia. A discussion of this extension of the peace thesis to decent but non-liberal societies follows below.

${ }^{7}$ There is some evidence that Walzer's has reconsidered his own commitment to the 'statist' position with which he is often identified. See, for example (2004: 186-189) which advocates for a plurality of global and regional institutions beyond the state. 
${ }^{8}$ Audard (2006: 66) agrees that if such peace is a feature of only democratic peoples then Rawls should also sanction democratising interventions into decent but non-liberal peoples. The response to Moellendorf outlined here is also, in part, a response to this concern.

${ }^{9}$ For a very clear summary of many such objections see Catherine (2007) chapter 5.

\section{References}

Audard, Catherine (2006) 'Cultural Imperialism and Democratic Peace'. In Rex Martin \& David A. Reidy (eds.), Rawls's Law of Peoples: A Realistic Utopia? (Oxford: Blackwell), pp. 59-75.

Audard, Catherine (2007) John Rawls. Stocksfield: Acumen.

Brown, Chris (2000) 'John Rawls, “The Law of Peoples”, and International Political Theory'. Ethics and International Affairs, 14, 125-32.

Hill Jr, Thomas E. (2012) 'Kant and Humanitarian Intervention'. In Hill Jr, Virtue, Rules and Justice: Kantian Aspirations. Oxford: Oxford University Press.

Kant, Immanuel (1996: originally 1797-8) The Metaphysics of Morals. Mary Gregor (ed.), Cambridge: Cambridge University Press.

Kant, Immanuel (1983: originally 1795) 'To Perpetual Peace: A Philosophical Sketch’. In Ted Humphrey (ed.) Perpetual Peace and Other Essays on Politics, History and Morals (Indianapolis: Hackett), pp. 107-143.

Maffettone, Sebastiano (2010) Rawls: An Introduction. Cambridge: Polity.

Martin, Rex \& Reidy David A. (eds.) (2006) Rawls's Law of Peoples: A Realistic Utopia? Oxford: Blackwell.

Mertens, Thomas (2002) 'From 'Perpetual Peace' to 'The Law of Peoples': Kant, Habermas and Rawls on International Relations'. Kantian Review, 6, 60-84. 
Moellendorf, Darrell (2014) 'Just War' In Jon Mandle \& David A. Reidy, (ed.s) A Companion to Rawls (Oxford: Wiley Blackwell), pp. 378-393.

Orend, Brian (2004) 'Kant's ethics of war and peace'. Journal of Military Ethics, 3, 161-177.

Orend, Brian (2006). The Morality of War Peterborough Ontario: Broadview Press.

Rawls, John (1999) The Law of Peoples: with 'The Idea of Public Reason Revisited'. Cambridge Mass.: Harvard University Press.

Toner, Christopher (2005). 'Just War and the Supreme Emergency Exemption'. Philosophical Quarterly, 55, 545-61.

Walzer, Michael (2004) Arguing About War. New Haven: Yale University Press.

Walzer, Michael (2006: originally 1977), Just and Unjust Wars: A Moral Argument with Historical Illustrations (4 ${ }^{\text {th }}$ edition). New York: Basic Books.

Williams, Howard (2012) Kant and the End of War: A Critique of Just War Theory. Basingstoke: Palgrave.

Williams, Huw (no date: unpublished article) 'The Path to Universal Peace: John Rawls and the Just War Doctrine'. 